\title{
ИСПОЛЬЗОВАНИЕ АНТИОКСИДАНТОВ В КАЧЕСТВЕ АДАПТОГЕНОВ ДЛЯ СВИНЕЙ (Sus scrofa domesticus Erxleben, 1777) (МЕТА-АНАЛИЗ)*
}

\author{
А.А. СЕМЕНОВА ${ }^{1}$, Т.Г. КУЗНЕЦОВА ${ }^{1}$, В.В. НАСОНОВА ${ }^{1}$, Р.В. НЕКРАСОВ ${ }^{2}$, \\ Н.В. БОГОЛЮБОВА², Е.Ю. ЦИС 2
}

Качество мяса, формируемое прижизненно, в основном определяет мышечная ткань. Поэтому изучение миопатических состояний, вызванных нарушениями режима кормления продуктивных животных и стрессами, представляет особый интерес. Разрабатываемые способы профилактики основаны главным образом на использовании природных адаптогенов и антиоксидантов в качестве кормовых добавок. Выполненный нами мета-анализ охватывает опубликованные в 19702020 годах результаты исследований стрессовых нагрузок и миопатических изменений в мышечной ткани у интенсивно растущих животных. Включение в рацион адаптогенов (селен, токоферол, кверцетины) позволяет контролировать гликолиз и оксидативный стресс через торможение перекисного окисления липидов и образования активных форм кислорода. Болышинство адаптогенов антиоксиданты, они способствуют укреплению сердечно-сосудистой системы животных, в том числе капиллярной, препятствуют вызванным свободными радикалами необратимым изменениям в клетках, предохраняя их от апоптоза и нормализуя состояние тканей и органов. На растущих свиньях разных пород и их сочетаний достаточно хорошо изучено применение витамина $E$ и его влияние на качество мяса при дозах от 10 до 1000 мг/кг корма (чаще около 200 мг/кг) и разных сроках скармливания. В то же время есть сообщения об отсутствии положительного влияния витамина Е на скорость роста свиней. Добавление к рациону свиней токоферола способствовало его накоплению во всех тканях, прежде всего в крови, печени, сердце, а также в других органах, в мышечной и жировой тканях. Витамин Е стабилизирует состояние мембран, снижает окисление липидов мембран, увеличивает общее количество жирных кислот в митохондриях клеток, повышает антиокислительную способность мышц и содержание мышечного гликогена. Было показано, что дополнительное накопление в мясе витамина $\mathrm{E}$ за счет его добавления в рацион в период откорма улучшает вкус, аромат, ослабляет характерный запах вторично разогретых блюд, не изменяет альдегидный профиль летучих веществ и снижает накопление азотистых летучих веществ, образующихся в результате распада белков при хранении мяса, в том числе в вакууме. Меньше внимания в современной научной литературе уделяется использованию селена как адаптогена в кормлении свиней. Показано, что селен в сочетании с повышенным количеством витамина Е способствовал уменьшению эффекта гипертермии у растущих свиней, повышению содержания в жире свободных жирных кислот. Использование селена в органической форме повышает антиоксидантный статус мышц. Сообщалось о разном влиянии селена в рационе на окисление белков и липидов при хранении мяса. Кверцетин и дигидрокверцетин (таксифолин) - широко известные флавоноиды с антиоксидантными свойствами. Доступные публикации по кверцетину и дигидрокверцетину в основном посвящены их биодоступности, способности накапливаться в тканях, влиянию на антиоксидантный статус и репродуктивные функции свиноматок, роли в нивелировании последствий транспортного стресса у свиней, а также в изменении качества мяса. Для свиней установлены эффективные дозы кверцетина (25-50 мг/кг массы животного) и дигидрокверцетина (1-3,5 мг/кг массы животного). Описано их положительное воздействие как в период роста и откорма животных, так и непосредственно перед убоем и транспортировкой. Однако исследования по оценке эффективности применения кверцетина и дигидрокверцетина с целью прижизненного формирования качества мяса немногочисленны, и этот вопрос требует дальнейшего изучения. Сообщалось, что у лабораторных животных кверцетин при длительном потреблении (до 6 мес, 0,2 \% от суточного рациона) уменьшает повреждение волокон в дистрофической скелетной мышце за счет снижения образования перекиси водорода в митохондриях. Таким образом, нутриенты-адаптогены и регуляторы направленного развития мышечной ткани, которые повышают ее устойчивость к воздействиям, нарушающим микроструктуры мышечной ткани, могут стать элементами интенсивных технологий производства мяса, применяемыми с целью прижизненного формирования его качества.

Ключевые слова: свиньи, стресс, свинина, миопатии, адаптоген, антиоксидант, селен, витамин Е, кверцетин, дигидрокверцетин.

Мышечная ткань как основная ткань организма животного, рассматривается в качестве главного компонента, обусловливающего качество

\footnotetext{
* Исследования проведены при финансовой поддержке РНФ по проекту № 19-16-00068.
} 
мяса, формируемое прижизненно (1). В связи с этим особый интерес представляет изучение факторов, влияющих на появление миопатических состояний животного, а также условий, способствующих нивелированию проявления таких физиологических отклонений.

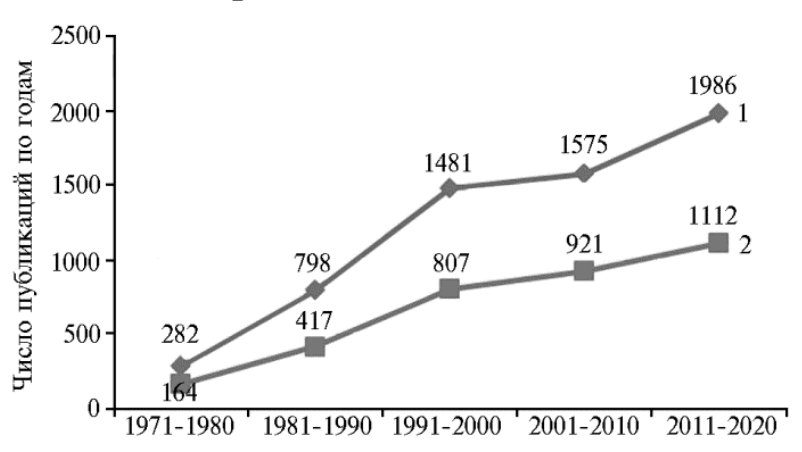

Рис. 1. Результаты поиска в ScienceDirect (https://www.sciencedirect.com) по запросам «myopathy», «stress» (1) и «food myopathy» (2).
Сбор исходной информации проводили в системе ScienceDirect по основным ключевым словам: «myopathy», «food myopathy», «muscle fiber», «pig», «stress», «pork quality», «pork PSE (pale soft exudative)». Было установлено, что число научных публикаций, посвященных изучению причин появления и прогрессирования миопатических состояний у человека, сельскохозяйствен-

ных и диких животных и птиц, насекомых, рыб, в том числе декоративных, возрастает с начала 1970-х годов прошлого века (рис. 1). Так, если в 19711980 годы в мире было опубликовано 282 работы по изучению развития миопатий, связанных с перенесенным стрессом, и 164 работы в области пищевой миопатии, то за последние годы (2011-2020) результаты поиска выявили соответственно 1986 и 1112 публикаций, то есть их число возросло примерно в 7 раз.

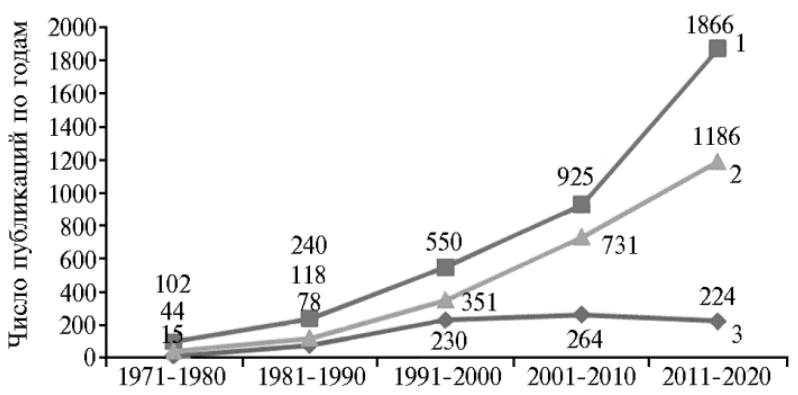

Рис. 2. Результаты поиска в ScienceDirect (https://www.sciencedirect.com) по запросам ««pork quality, stress» (1), «muscle fiber, pork quality» (2) и «pork PSE» (3, PSE - pale soft exudative). числа публикаций, посвященных изучению состояния мышечных волокон с точки зрения обеспечения качества свинины (рис. 2).

Следует отметить, что еще недавно при оценке качества свинины ее относили к мясу с нормальным течением автолиза, или к так называемому мясу PSE (pale soft exudative - бледное, мягкое, экссудативное), то есть имеющему свойства, которые делают его сухим и непривлекательным для потребителя. Интересно, что анализ числа научных публикаций, которые посвящены этому пороку качества, за последние 10 лет показал наличие тенденции к их сокращению (см. рис. 2).

Как видно из рисунка 2, максимальное число публикаций, содержащих слова «pork» и «PSE», приходилось на период 2001-2010 годов. На наш взгляд, наблюдаемая тенденция объясняется не стабилизацией качества свинины, а скорее изменением представлений большинства специалистов о 
механизмах и способах обеспечения его формирования. Об этом свидетельствует рост числа публикаций, посвященных изучению качества свинины во взаимосвязи как с характеристиками мышечных волокон, так и с влиянием стресса.

Разработка способов профилактики миопатических состояний различной этиологии основывается главным образом на анализе возможности использовать природные адаптогены и антиоксиданты в кормлении продуктивных животных. Известно, что многие препараты природного (растительного или животного) и синтетического происхождения оказывают стимулирующее действие на нервную систему и организм в целом. Такие вещества, обладая специфическим иммуностимулирующим и анаболическим действием, стимулируют гуморальный ответ посредством сенсибилизации В-лимфоцитов (синтез иммуноглобулинов), а также Т-лимфоцитов (тимусзависимых клеток), обеспечивающих клеточный иммунный ответ (2). Витамины (в частности, токоферолы), а также микроэлементы (в первую очередь селен) - наиболее распространенные в свиноводстве вещества с антиоксидантными и адаптогенами свойствами. Изучение природных адаптогенов - биофлаваноидов, содержащихся в растениях, составляет одно из актуальных направлений исследований, поэтому для сбора информации проводили поиск публикаций с использованием дополнительных ключевых слов «vitamin E», «tocopherol», «selenium», «dihydroquercetin», «quercetin». Для анализа отбирали публикации, которые содержали в названии и/или в аннотации, и/или в ключевых словах хотя бы по одному из указанных основных и дополнительных ключевых слов; были оригинальными статьями, подготовленными авторами по результатам собственных исследований на растущих свиньях; включали информацию о дозах витамина Е, селеносодержащих добавок и кверцетинов/дигидрокверцетина по отдельности и/или в сочетании друг с другом, и/или в сочетании с другими пищевыми компонентами); представляли данные, полученных после убоя животных; датировались не ранее 1995 года.

В анализируемый массив данных входила следующая информация, представленная в виде таблиц: сведения о животных, которых отбирали для экспериментов по кормлению (начальная масса, возраст, породы свиней, породосочетания и т.п.); доза адаптогена в рационе; продолжительность скармливания адаптогена (адаптогенов); достигнутые эффекты.

В и там и н Е. Включение в рацион адаптогенов (селен, токоферол, кверцетины) позволяет контролировать гликолиз и оксидативный стресс посредством торможения образования продуктов перекисного окисления липидов и активных форм кислорода. Большинство адаптогенов - антиоксиданты, они способствуют укреплению сердечно-сосудистой системы, в том числе капиллярной, препятствуют разрушению клеток свободными радикалами, предохраняя их от апоптоза, поддерживают нормальное функционирование тканей и органов.

Применение витамина Е и его влияние на качество мяса достаточно хорошо изучено на растущих свиньях разных пород и породосочетаний. Из 28 публикаций, пригодных для мета-анализа, 27 были посвящены изучению роли витамина Е в производстве свинины и одно - развитию пищевой миопатии у пресноводных рыб Danio rerio семейства Карповые при дефиците витамина Е. В этом исследовании получены результаты, которые важны для понимания роли витамина Е в развитии пищевых миопатий. В частности, показано, что недостаток витамина Е в рационе вызывал вялое поведение, связанное с многоочаговой многофазной дегенеративной миопатией скелетных мышц. Проявления миопатии по степени тяжести 
варьировали от рассеянного острого некроза до распространенного фиброза. Добавление витамина Е к рациону рыб позволило сохранить в мышцах увеличенное в 2 раза содержание аскорбиновой кислоты $(\mathrm{p}<0,001)$ при 3кратном снижении количества малонового альдегида $(\mathrm{p}<0,001)$, что подтверждало высокий антиокислительный статус мышц. Напротив, дефицит витамина Е вызывал усиление окислительного стресса и вторичное снижение содержания аскорбиновой кислоты, что приводило к серьезному повреждению мышечной ткани и нарушению мышечной функции (2).

В исследованиях на растущих свиньях и свиньях на заключительном откорме сравнивали разные дозы витамина E - от 10 до 1000 мг/кг корма. Чаще всего использовалась дозировка 200 мг/кг корма (4-12). Сравнивали разную продолжительность скармливания витамина $\mathrm{E}$ - от минимальной (за 1 сут до убоя) до 70 сут, а также в период изменения массы свиней от начальной до требуемой для направления на убой (от 105 до 135 кг). Изучение влияния витамина Е на состояние животных перед убоем и качество мяса показало, что токоферол даже за 1 сут до убоя увеличивал запасы гликогена в мышцах на $10 \%$, а также повышал влагосвязывающую способность (BCC), особенно при применении кормовой добавки в сочетании с умеренной физической активность животных (13). Однако эти выводы были оспорены в 2004 году в масштабном эксперименте $(n=92)$, в котором было установлено, что дополнение рациона свиней витамином Е за 5 сут до убоя не увеличивало его концентрацию в мышцах, не способствовало улучшению ВСС и цвета мяса. Авторы сделали вывод, что при стрессе, уровень которого ниже, чем при обычных процедурах, связанных с убоем, кратковременное введение в рацион добавок, по-видимому, не влияет на качество мяса (14).

В целом мета-анализ выявил 16 ожидаемых эффектов от применения витамина Е в качестве кормовой добавки (табл. 1). В четырех работах с достаточно большим объемом экспериментальных данных авторы пришли к выводу, что витамин Е в количестве 140-220 мг/кг корма не влияет на показатели роста свиней даже при продолжительном скармливании, в том числе в сочетании с витамином С (14-17). Такой вывод, очевидно, надо рассматривать как неоднозначный и не окончательный или как соответствующий только изученному диапазону доз токоферола в корме: витамин Е - биологически активная и необходимая добавка, его дефицит способен вызывать пищевые миопатии, а следовательно, снизить скорость роста животных. В одной работе (17) отмечалось, что витамин Е в количестве 220 мг/кг корма снижал $(\mathrm{p}<0,36)$ его эффективность. При этом даже длительное введение токоферола в рацион в количестве 140 мг/кг корма не влияло на убойные показатели - выход продуктов убоя к живой массе свиней (15), а также на качественные характеристики свиных туш (10). В другом исследовании (17) длительное введение витамина Е привело к увеличению массовой доли мышечной ткани в туше.

В 14 исследованиях авторы анализировали накопление витамина E в органах и тканях свиней. Результаты однозначно свидетельствовали о том, что введение в рацион свиней токоферола способствовало его аккумуляции во всех тканях, прежде всего в крови, печени, сердце, а также в мышечной и жировой тканях. Максимальное увеличение количества витамина Е в мышечной ткани достигалось за 28 сут при дозе 200 мг/кг корм. Дальнейшее увеличение содержания витамина Е в мышцах уже не происходило. Сообщалось также, что синтетический токоферол (смесь восьми соединений, не представленных в природе) способен замещать в организме животных природный токоферол $(4,7,9,14-16,18-25)$. 
1. Мета-анализ данных по применению витамина Е в качестве адаптогена в свиноводстве (ScienceDirect, 1995-2019 годы)

\begin{tabular}{|c|c|c|c|c|c|}
\hline \multirow[b]{2}{*}{ Предполагаемый эффект } & \multirow{2}{*}{$\begin{array}{l}\text { Число животных } \\
\text { в экспериментах }\end{array}$} & \multicolumn{2}{|c|}{ Применение витамина Е } & \multirow[b]{2}{*}{ Вывод } & \multirow[b]{2}{*}{ Источники } \\
\hline & & $\begin{array}{l}\text { дозы, мг/кГ } \\
\text { корма }\end{array}$ & период & & \\
\hline Показатели роста свиней & 246 & $140-220$ & $\begin{array}{l}\text { С } 25 \text { до } 110 \text { кг живой } \\
\text { массы }\end{array}$ & $\begin{array}{l}\text { I Не влияет даже при продолжительном скармливании и в сочетании витами- } \\
\text { ном С }\end{array}$ & $(10,15-17)$ \\
\hline Эффективность усвоения корма & 48 & 220 & $\begin{array}{l}\text { С } 54 \text { до } 113 \text { кг живой } \\
\text { массы }\end{array}$ & Снижает $(\mathrm{p}<0,36)$ & $(17)$ \\
\hline Убойные показатели & Не сообщается & 140 & $\begin{array}{l}\text { С } 25 \text { до } 105 \text { кг живой } \\
\text { массы }\end{array}$ & $\begin{array}{l}\text { 1 Не влияет даже при длительном скармливании, в том числе совместно с ви- } \\
\text { тамином С }\end{array}$ & $(15)$ \\
\hline $\begin{array}{l}\text { Качественные характеристики } \\
\text { туш }\end{array}$ & 198 & $200-220$ & $\begin{array}{l}\text { С } 54 \text { до } 113 \text { кг живой } \\
\text { массы }\end{array}$ & Не влияет. Возможно увеличение массовой доли мышечной ткани в туше & $(10,17)$ \\
\hline $\begin{array}{l}\text { Содержание витамина Е в крови, } \\
\text { органах, мышечной и жировой } \\
\text { ткани животного }\end{array}$ & 154 & $100-1000$ & От 5 до 70 сут & $\begin{array}{l}\text { Увеличивает в зависимости от дозы при длительном применении. Макси- } \\
\text { мальное увеличение в мышечной ткани на } 28 \text {-е сут }\end{array}$ & $\begin{array}{l}(4,7,9,14-16 \\
18,20-25)\end{array}$ \\
\hline $\begin{array}{l}\text { Состояние клеточных мембран и } \\
\text { митохондрий }\end{array}$ & Не сообщается & $200-1000$ & От 46 сут & $\begin{array}{l}\text { Стабилизирует состояние мембран, снижает окисление липидов мембран и } \\
\text { увеличивает общее количество жирных кислот в митохондриях }\end{array}$ & $(4,8,19,26)$ \\
\hline Состояние мышечной ткани & 56 & 500 & $\begin{array}{l}\text { От } 2 \text { сут до заверше- } \\
\text { ния откорма }\end{array}$ & $\begin{array}{l}\text { Повышает антиокислительную способность, содержание гликогена в мыш- } \\
\text { цах. Дефицит витамина Е вызывает повреждения мышечной ткани (дегене- } \\
\text { ративная миопатия) }\end{array}$ & $(2,13,23)$ \\
\hline $\begin{array}{l}\text { Тяжесть последствий } \\
\text { транспортного стресса }\end{array}$ & 288 & 200 & 28 сут & $\begin{array}{l}\text { Не влияет, в том числе не снижает содержание креатинкиназы и кортизола в } \\
\text { сыворотке крови, экспрессию белков теплового шока в мышечной ткани, } \\
\text { повреждение эпителия кишечника }\end{array}$ & в (12) \\
\hline $\begin{array}{l}\text { Накопление внутримышечного } \\
\text { жира и общий химический состав } \\
\text { мышечной ткани }\end{array}$ & 282 & $100-220$ & $\begin{array}{l}\text { От } 38 \text { сут; от } 54 \\
\text { до } 135 \text { кг живой } \\
\text { массы }\end{array}$ & $\begin{array}{l}\text { В целом, очевидно, не влияет, хотя имеются данные о том, что повышает } \\
\text { оценку мраморности }\end{array}$ & $(5,17,27)$ \\
\hline $\begin{array}{l}\text { Жирнокислотный состав } \\
\text { внутримышечного жира }\end{array}$ & 224 & $100-325$ & От 28 сут и более & $\begin{array}{l}\text { Данные противоречивы: или не влияет, или увеличивает содержание полине- } \\
\text { насыщенных жирных кислот }\end{array}$ & $(5,28)$ \\
\hline $\begin{array}{l}\text { рН, влагосвязывающая } \\
\text { способность (ВСС) и доля мяса } \\
\text { PSE (pale soft exudative) }\end{array}$ & 1060 & $80-1000$ & $\begin{array}{l}\text { От } 2 \text { до } 46 \text { сут; с } 54 \\
\text { до } 110 \text { кг живой } \\
\text { массы и до убоя }\end{array}$ & $\begin{array}{l}\text { Нет однозначного понимания влияния витамина Е на рН, ВСС и появление } \\
\text { мяса PSE }\end{array}$ & $\begin{array}{l}(5,8,11-14 \\
16,17,22,25 \\
26,28)\end{array}$ \\
\hline $\begin{array}{l}\text { Накопление продуктов окисли- } \\
\text { тельной порчи }\end{array}$ & 974 & $10-700$ & $\begin{array}{l}\text { От } 28 \text { до } 150 \text { сут, } \\
\text { от } 25 \text { до } 135 \text { кг } \\
\text { живой массы }\end{array}$ & $\begin{array}{l}\text { Продукты вторичного окисления (тиобарбитуровое число - ТБЧ или гекса- } \\
\text { наль): снижает динамику их накопления в мясе; в отдельных случаях витамин } \\
\text { Е не влиял на ТБЧ (две работы из 11). Перекисное число (ПЧ) снижает (не } \\
\text { снижалось в одном случае из трех) }\end{array}$ & $\begin{array}{l}(2,5,7,10,11 \\
15,16,20,21 \\
25,27,29,30)\end{array}$ \\
\hline
\end{tabular}


Общая органолептическая

оценка

Цвет мяса

Вкус и запах мяса
100-500 В п период откорма до убоя

0-1000 От 5 до 70 сут

от 51 до $113 \mathrm{Kг}$

живой массы

10-210 В период откорма до убоя

200-500 В период откорма до убоя
Не влияет

Продолжение таблицы

$$
(5,23)
$$

Нет однозначного понимания влияния на цвет в целом: улучшает или не влияет. Краснота: улучшает показатель, в отдельных случаях не оказывает $14,17,18,21-$ влияния; повышает красноту продуктов с нитритом. Светлота: значительный $23,25,27,30$ ) положительный эффект при хранении мяса

Положительно влияет на запах и вкус, усиливает их интенсивность. Снижает $(9,16,22)$

выраженность запаха вторично разогретых блюд. Не влияет на альдегидный

профиль летучих веществ и снижает накопление азотистых летучих веществ

при хранении в вакууме

Данные противоречивы: не влияет или повышает

$(16,23)$ 
Результаты проанализированных работ также позволили сделать вывод о том, что витамин Е стабилизирует состояние мембран, снижает окисление липидов мембран и увеличивает общее количество жирных кислот в митохондриях $(8,19,26)$.

Влияние витамина Е на состояние мышечной ткани свиней исследовалось мало. Поиск выявил всего две работы $(13,23)$, результаты которых показывают, что витамин Е повышает антиокислительную способность и содержание гликогена в мышцах.

Изучалась возможность смягчения последствий транспортного стресса у свиней посредством добавления в их рацион витамина Е за 28 сут до транспортировки. Однако ожидаемый эффект достигнут не был. Оказалось, что витамин Е не влияет на клинические проявления этой патологии, в том числе не снижает содержание креатинкиназы и кортизола в сыворотке крови, экспрессию белков теплового шока в мышечной ткани, повреждение эпителия кишечника (12).

Рассматривалось влияние витамина Е на накопление внутримышечного жира и общий химический состав мышечной ткани. В целом был сделан вывод об отсутствии взаимосвязи между этими факторами, несмотря на данные о повышении оценки мраморности свинины $(5,17,27)$. Последнее могло быть связано с изменением восприятия цвета, а не с накоплением жира в длиннейшей мышце спины.

Данные, полученные при оценке воздействие витамина Е на жирнокислотный состав внутримышечного жира, противоречивы: отмечалось как отсутствие взаимосвязи (5), так и увеличение доли полиненасыщенных жирных кислот (ПНЖК) в мышечной ткани свиней при введении витамина Е в рацион (28).

В 12 исследованиях рассматривалась возможность снизить долю PSE свинины, повысить рН и ВСС мяса $(5,8,11-14,16,17,22,25,26,28)$. Сообщалось, что в больших дозах (1000 мг/кг) витамин Е может стабилизировать клеточные мембраны и регулировать избыточное высвобождение $\mathrm{Ca}^{2+}$, предотвращая образование мяса с пороком PSE и одновременно улучшая влагосвязывающую способность мышечной ткани (26). Хотя повышение ВСС при разных дозах витамина Е в рационе животных отмечалось в ряде исследований, однозначного вывода сделать не удалось, несмотря на полномасштабные исследования на большой выборке животных и при значительной длительности экспериментов. Мнения разделились примерно поровну: в одной часть публикаций делается заключение об отсутствии влияния витамина Е на рН и ВСС, в другой - что введение витамина Е в рацион свиней способно снизить долю мяса PSE. В качестве причины можно предположить, что даже при экспериментальном убое крайне сложно создать для всех животных одинаковые стрессовые нагрузки, а также учесть их индивидуальные особенности восприятия стрессовых ситуаций.

В 13 работах представлены данные по динамике накопления продуктов окислительной порчи при хранении как мяса, так и готовых продуктов из мяса от животных, в рацион которых вводили витамин Е в количестве от 10 до 700 мг/кг корма (2, 5, 7, 10, 11, 15, 16, 20, 21, 25, 27, 29, 30). Результаты этих работ свидетельствовали о торможении развития окислительных процессов в мясе и мясной продукции при продолжительном (от 28 сут) применения токоферола в период откорма. Лишь при некоторых условиях (возможно, в зависимости от нутриентного состава кормов) такой эффект не достигался.

В двух работах $(5,23)$ изучали влияние витамина Е в рационе свиней на общую органолептическую оценку получаемой свинины. Результаты 
показали отсутствие эффекта при длительном применении в период откорма в дозах 100-500 мг/кг корма.

Возможности стабилизации и улучшения цвета и цветовых характеристик свинины ( $\mathrm{L}$ - светлота, a - краснота, $\mathrm{b}$ - желтизна) было уделено внимание в 13 исследованиях $(5,7,10,11,14,17,18,21-23,25,27,30)$. Результаты не дали однозначного ответа, влияет ли витамин Е на цвет свинины. По крайней мере, понятно, что увеличение количества токоферола в рационе и в мясе не приводило к ухудшению показателей цвета даже при наибольших дозировках - 1000 мг/кг корма. В отношении инструментально измеряемых показателей цвета (краснота и светлота) мета-анализ выявил их улучшение в случае мяса, реализуемого в упакованном виде, кроме того, в мясном сырье витамин Е эффективно повышает красноту продуктов, изготовленных с нитритом.

Влияние витамина Е на вкус и запах определено как положительное по результатам трех исследований $(9,16,22)$. При использовании в период откорма витамина Е в качестве добавки его содержание в мясе увеличивалось, что повышало интенсивность вкуса и аромата, кроме того, запах вторично разогретых блюд, который рассматривается как нежелательный, был менее выражен. В качестве положительных можно рассматривать данные о том, что витамин Е не изменяет альдегидный профиль летучих веществ мяса и снижает накопление азотистых летучих веществ, образующихся в результате распада белковых веществ при хранении, в том числе в вакууме.

Исследование влияния витамина Е на нежность мяса $(16,23)$, как и в случае влияния на ВСС, дало противоречивые результаты (или не влияет, или повышает). Эти данные согласуются с результатами по ВСС.

Таким образом, судя по активности исследований, большинство ученых продолжают рассматривать витамин Е как важный нутриент, который способен обеспечить достижение высоких потребительских характеристик продуктов убоя в свиноводстве, применяться для стабилизации цвета, вкуса, аромата, а также для эффективного подавления окислительных процессов при производстве и хранении мясной продукции.

С елен. Поиск публикаций по применению селена в кормлении свиней (период с 1999 по 2020 год) выявил 20 работ, пригодных для метаанализа, то есть исследования по селену ведутся менее интенсивно, чем по витамину Е. Общее число проверяемых гипотез о возможных эффектах селена также меньше - 11 (табл. 2).

Селен вводили в рацион в неорганическом (селенит натрия) и органическом (Se-обогащенные дрожжи и селенометионин) виде при широком диапазоне дозировок - от 0,045 до 50 мг/кг корма, а также совместно с витамином Е и при одновременном введении в корм жиров, богатых ненасыщенными жирными кислотами. Наиболее часто использовались дозы 0,2-0,3 мг/кг корма. Продолжительность экспериментов достигала 65 сут. Масса животных в эксперименте - от начальной массы 10 кг до конечной массы 160 кг.

Влияние введения селена в рацион свиней на убойные показатели оценено в двух исследованиях $(31,32)$ на общей выборке 479 особей. При высоких дозах селена (до 30 мг/кг корма) и продолжительном скармливании (в одной работе - от начальной массы животных 20 кг до финишной 105 кг, в другом - 30 сут) не было выявлено эффекта как неорганического, так и органического селена, кроме селенометионина. У животных, получавших его в качестве источника селена, выход туш при убое был выше. При аналогичных условиях экспериментов было установлено, что селен (в органической и неорганической форма, а также в сочетании с витамином Е) не 
влиял на качественные характеристики свиных туш $(31,33)$.

Семь исследований было посвящено влиянию селена в корме на его содержание в крови, органах, мышечной ткани животных. Эксперименты были проведены на репрезентативной выборке животных $(n=603)$ и при разных дозировках (0,045-50 мг/кг). Животных отбирали по начальной живой массе (от 20 до 60 кг) или возрасту (30-40 сут), скармливание дополнительного селена продолжали до убоя.

Накопление селена в тканях происходит быстрее в случае органического селена, особенно селенометионина, и способствует накоплению витамина Е. Наиболее эффективной была признана ежедневная суточная доза селена 0,4 мг/кг корма. Интересно, что при таком суточном поступлении молодой здоровый организм после 28 сут перестает запасать селен $(31,32$, 34-38).

В трех исследованиях $(36,39,40)$ оценили эффект, оказываемый селеном на состояние мышечной ткани животных. Результаты длительных экспериментов (26 сут и более) позволили сделать вывод об отсутствии такого эффекта, в том числе при сочетании селена с витамином Е. Не было выявлено никаких изменений микроструктуры мяса (независимо от источника селена). Тем не менее при созревании мяса селен (Se-дрожжи, селен с витамином Е) усиливал деструктивные изменения на 8-е сут, что, вероятно, связано с более высокой активностью тканевых ферментов.

Возможность нивелирования последствий транспортного стресса свиней за счет дополнительного введения селена в рацион изучали в одной работе (41) на 36 животных в доза от 0,24 до 1 мг/кг, причем на фоне потребления витамина Е (17-100 мг/кг). Результаты наглядно показали, что селен уменьшал эффекты гипертермии у растущих свиней.

Изучение жирнокислотного состава внутримышечного жира у животных, которым давали селен на фоне базового и дополнительного потребления витамина Е, выявило повышение содержания в жире свободных жирных кислот под влиянием органического селена. Эффект усиливает витамин E: содержание $\mathrm{C}_{18: 1}$ увеличивается, $\mathrm{C}_{18: 0}$ - снижается (38). Влиянию селена на $\mathrm{pH}$, влагосвязывающую способность и долю мяса PSE было посвящено восемь масштабных по числу животных $(n=689)$ и продолжительности исследований. Результаты позволяют сделать однозначный вывод о том, что органический селен повышает ВСС и рН $(31,32,35,38,39,42-44)$. Вместе с тем неясно, чем объяснить такой положительный эффект и почему он не согласуется с данными исследований состояния мышечной ткани.

Наиболее изучено влияние дополнительного селена на окислительные процессы прижизненно, а также при хранении мяса и мясной продукции. Однозначен вывод, что органический селен повышает антиоксидантный статус мышц. Однако введение в рацион селена по-разному влияло на окисление белков и липидов при хранении мяса. Результаты исследований неоднозначны: в одних работах получены данные, позволяющие сделать вывод о снижении окисления под влиянием селена, в других, напротив, показано, что селен не способен тормозить накопление продуктов окислительной порчи $(32,34-36,38,39,42,44-48)$.

В двух публикациях $(33,49)$ делается вывод, что селен и витамин Е не влияют на общую органолептическую оценку свинины. Однако в отношении цвета мяса результаты различались, что объяснялось формой введения адаптогенов, а также, возможно, выбором дозы и объектов исследования. Так, неорганический селен не влиял на цветовые показатели или ухудшал их, а органический селен, напротив, либо не влиял, либо улучшал цветовые показатели. Попытка оценить эффект совместного введения в рацион селена и витамина Е была сделана лишь в одном исследовании (50), 
2. Мета-анализ данных по применению селена в качестве адаптогена в свиноводстве (ScienceDirect, 1999-2019 годы)

\begin{tabular}{|c|c|c|c|c|c|}
\hline \multirow{2}{*}{ Предполагаемый эффект } & \multirow{2}{*}{$\begin{array}{l}\text { Число животных } \\
\text { в экспериментах }\end{array}$} & \multicolumn{2}{|c|}{ Применение селена } & \multirow{2}{*}{ Вывод } & \multirow{2}{*}{ Источники } \\
\hline & & дозы, мг/кг корма & период & & \\
\hline Убойные показатели & 479 & $0,05-30$ & $\begin{array}{l}\text { С } 20 \text { до } 105 \text { кг; } \\
30 \text { сут }\end{array}$ & $\begin{array}{l}\text { Нет влияния при использовании как неорганического, так и ор- } \\
\text { ганического селена (кроме селенометионина, который повышает } \\
\text { выход туши) }\end{array}$ & $(31,32)$ \\
\hline Качественные характеристики туш & 399 & 0,05-30 & $\begin{array}{l}\text { С } 20 \text { до } 105 \text { кг, } 28 \\
\text { и } 49 \text { сут }\end{array}$ & $\begin{array}{l}\text { Нет влияния при введении в рацион селена в органической и не- } \\
\text { органической форме, а также в сочетании с витамином E }\end{array}$ & $(31,33)$ \\
\hline $\begin{array}{l}\text { Содержание селена в крови, органах, } \\
\text { мышечной ткани животного }\end{array}$ & 603 & $0,045-50$ & $\begin{array}{l}\text { С } 20-60 \text { кг до убоя; } \\
30-40 \text { сут }\end{array}$ & $\begin{array}{l}\text { Накопление селена в тканях животного происходит быстрее при } \\
\text { кормлении органическим селеном, особенно селенометионином, } \\
\text { и способствует накоплению витамина Е. Наиболее эффективная } \\
\text { концентрация }-0,4 \text { мг/кг корма }\end{array}$ & $\begin{array}{l}(31,32,34-37 \\
42)\end{array}$ \\
\hline Состояние мышечной ткани & Не сообщается & $0,2-0,4$ & $\begin{array}{l}\text { От } 26 \text { сут; с } 75 \text { до } \\
160 \text { кг }\end{array}$ & $\begin{array}{l}\text { В гистологических исследованиях не выявлено влияния селена, в } \\
\text { том числе с витамином Е, на состояние мышц свиньи (кроме } \\
\text { того, что при созревании мяса селен - Se-дрожжи, селен с вита- } \\
\text { мином Е - усиливает деструктивные изменения на 8-е сут) }\end{array}$ & $(36,39,40)$ \\
\hline $\begin{array}{l}\text { Тяжесть последствий транспортного } \\
\text { стресса }\end{array}$ & 36 & $\begin{array}{l}0,24-1 \text { (с витамином Е, } \\
17-100 \text { мг/кг) }\end{array}$ & 14 сут & Уменьшение эффектов гипертермии у растущих свиней & $(44)$ \\
\hline $\begin{array}{l}\text { Жирнокислотный состав внутримы- } \\
\text { шечного жира }\end{array}$ & $\begin{array}{l}\text { Не сообщается } \\
\text { (изучалось мясо) }\end{array}$ & 0,2-0,4 (с витамином Е) & $\begin{array}{l}\text { Не сообщается } \\
\text { (изучалось мясо) }\end{array}$ & $\begin{array}{l}\text { Органический селен способствует повышению содержания в } \\
\text { жире свободных жирных кислот (эффект усиливает витамин Е). } \\
\text { Se увеличивает содержание C18:1 и снижает - C18:0 }\end{array}$ & $(42)$ \\
\hline $\begin{array}{l}\text { pH, влагосвязывающая способность } \\
\text { (BCC) и доля мяса PSE (pale soft exu- } \\
\text { dative) }\end{array}$ & 689 & 0,05-30 & $\begin{array}{l}26-65 \text { сут; с } 20-30 \\
\text { до } 105-130 \text { кГ }\end{array}$ & Органический селен повышает ВСС и рН & $\begin{array}{l}(31,32,35,38 \\
42-44)\end{array}$ \\
\hline $\begin{array}{l}\text { Накопление продуктов окислительной } \\
\text { порчи }\end{array}$ & 438 & 0,045-3 & $26-65$ сут & $\begin{array}{l}\text { Органический селен повышает антиоксидантный статус мышц, } \\
\text { однако, его влияние на окисление белков и липидов при хране- } \\
\text { нии мяса не однозначно - снижает или не влияет }\end{array}$ & $\begin{array}{l}(32,34-36,38 \\
39,42,44-47)\end{array}$ \\
\hline Общая органолептическая оценка & 107 & Селен (с витамином Е) 2 & $28-49$ сут & Не влияет & $(33,49)$ \\
\hline Цвет мяса & 380 & $0,045-0,5$ & $\begin{array}{l}30-65 \text { сут; с } 20 \text { до } \\
105 \text { кг }\end{array}$ & $\begin{array}{l}\text { Нет однозначного понимания. Неорганический селен не влияет } \\
\text { или ухудшает цветовые показатели, а органический селен не вли- } \\
\text { яет или улучшает цветовые показатели }\end{array}$ & (48) \\
\hline Вкус и запах мяса & $\begin{array}{l}\text { Не сообщается } \\
\text { (изучалось мясо) }\end{array}$ & $\begin{array}{l}1 \text { (с витамином Е, } \\
100 \text { мг/кг корма) }\end{array}$ & $\begin{array}{l}\text { Не сообщается } \\
\text { (изучалось мясо) }\end{array}$ & Влияет незначительно & $(50)$ \\
\hline
\end{tabular}


в котором такой эффект был признан незначительным.

В целом селену как адаптогену, важному для прижизненного формирования качества мяса, на наш взгляд, уделяется недостаточно внимания.

Кверцетин и дигидрокверцетин. Кверцетин и дигидрокверцетин (таксифолин) - широко известные и хорошо изученные флавоноиды. Они не токсичны, обладают выраженными антиоксидантными и антимикробными свойствами, вследствие чего их используют как в процессе производства продукции животноводства, так и при ее переработке и хранении.

Число публикаций требуемой тематики, пригодных для мета-анализа, оказалось ограниченным - 23 статьи (выборку дополнили отечественными источниками, ранее известными авторам настоящего мета-анализа), относящиеся к периоду с 1999 года по настоящее время (табл. 3) и охватывающие результаты исследований биодоступности этих флавоноидов, их накопления в тканях животных, влияния на репродуктивные функции свиноматок, антиокислительный статус животных, снижение последствий транспортного стресса, качество мяса.

Биодоступность кверцетина из гликозидов кверцетина определяется сложной взаимозависимостью между химическими формами флавоноидов и составом рациона (видами кормов) $(51,52)$.

Накопление кверцетина в тканях свиней в результате добавления флавоноида в корм достаточно подробно изучено во многих работах. Основной метаболит кверцетина, выявляемый в плазме крови через 24 ч после поступления этой добавки в организм, - конъюгированный кверцетин (52). Наибольшее содержание кверцетина и его метаболитов отмечают в органах, ответственных за выведение продуктов метаболизма, - в печени и почках (соответственно 5,87 и 2,51 нмоль/г ткани), достоверно наименьшее - в мозге, сердце и селезенке. При этом у свиней в плазме крови и в сердце кверцетин накапливается медленнее и в меньших количествах, чем у крыс, тогда как его накопление в почках, мозге, селезенке у этих животных не различается. Содержание кверцетина в плазме крови свиней после 3 сут потребления высоких доз кверцетина (до 500 мг/кг) не превышало 1,25 ммоль/л (53, 54). Также не установлено различий между результатами длительного и многократного применения этого флавоноида и однократного применения (55). Таким образом, доказано, что скармливание кверцетина безопасно для животных ввиду отсутствия его накопления в тканях $(53,55)$.

Из диетических факторов на биодоступность кверцетина влиял жир в рационе (в зависимости от содержания) (52). При этом сочетание витамина Е с кверцетином приводит к лучшему положительному эффекту (56).

Интерес ученых к изучению влияния кверцетина на репродуктивную функцию свиней сохраняется уже более 10 лет (57-60). Установлено, что кверцетин не влияет на рост гранулезных клеток, но (в зависимости от дозы) ингибирует продукцию прогестерона и модифицирует продукцию экстрадиола $17 \beta$. Возможно негативное влияние кверцетина на физиологический статус яичников. Кроме того, флавоноид вмешивается в ангиогенный процесс посредством ингибирования продукции VEGF (фактора роста эндотелия сосудов), а также через изменения окислительно-восстановительного статуса (57). Экзогенные флавоноиды снижали содержание активных форм кислорода (АФК) в ооцитах, но при высокой концентрации (50 мкг/мл) оказались токсичными для ооцитов (58). Кверцетин проявляет ингибирующее действие на основные функции яичников, не предотвращает и не смягчает воздействия бензола на репродуктивные процессы, усиливает влияние бензола на высвобождение прогестерона (60).

Кверцетин не влиял на активность глутатионпероксидазы, глутати- 
онредуктазы и глутамат-цистеинлигазы в слизистой тонкого кишечника и печени поросят после отъема, при этом активность печеночной глутатионтрансферазы значительно повышалась на 5-е сут после отъема при приеме кверцитина в дозах 100, 300 и 900 мг/кг. Оценка содержания малонового альдегида в плазме крови, печени и тонком кишечнике показала, что данные о воздействии кверцетина на кинетику глутатиона у поросят-отъемышей противоречивы, и вопрос требует дальнейшего изучения (61). Кверцетин способствует защите энтероцитов кишечника свиней от окислительного стресса (62). Установлено, что при контаминации кормов микотоксинами у животных, получавших кверцетин (отдельно или в комбинации с витаминами и селеном) частично восстанавливался оксидантный статус (63).

Применение дигидрокверцетина в кормлении поросят блокирует процесс перекисного окисления липидов в течение всего периода выращивания и откорма, особенно при воздействии высоких температур. Кислотное, перекисное число и содержание малонового диальдегида в сыворотке крови поросят при использовании дигидрокверцетина снижаются, а антиоксидантная защита организма усиливается, что выражается в повышении антиокислительной активности плазмы крови. Отмечается улучшение функций печени. В совокупности это положительно отражается на суточных приростах и сохранности свиней (64-67).

Кверцетины уменьшают степень воздействия транспортного стресса, способствуя снижению сывороточной концентрации эндотоксина, количества АФК и малонового диальдегида (МДА) в тканях кишечника, в тощей кишке свиней отмечается увеличение высоты ворсинок с одновременным снижением экспрессии воспалительных цитокинов (68).

Влияние кверцетина и дигидрокверцетина на качество мяса изучено достаточно подробно (в отношении различных технологических и потребительских характеристик на разных стадиях производства - от парных туш до замороженного мяса при длительном хранении). Добавление в рацион поросят кверцетина в период откорма и даже за 4 ч до убоя замедлило скорость снижения $\mathrm{pH}$ в мышечной ткани. Однако конечное значение $\mathrm{pH}$ через 24 ч после убоя не зависело от рациона. Отмечено повышение влагосвязывающей способности мяса и снижение потерь массы при хранении в условиях розничной торговли в течение 12 сут (69). Адаптогены (дигидрокверцетин в дозе 3,5 мг/кг живой массы и лепестки роз в дозе 0,255 мг/кг живой массы) способствовали снижению накопления первичных и вторичных продуктов окисления липидов в процессе хранения как в мышцах, так и в жире. Незначительный положительный эффект отмечен по рН и цвету свинины $(67,70)$. Установлены эффективные для свиней дозы кверцетина - 2550 мг/кг массы животного $(55,58)$ и дигидрокверцетина -1 мг/кг массы животного (64-66) и 3,5 мг/кг живой массы $(67,70)$, а также факт, что флавоноиды эффективны при скармливании как в процессе роста животных $(55,65)$, так и непосредственно перед убоем, транспортировкой $(68,69,71)$.

Анализ опубликованных данных показывает, что роль кверцетина и дигидрокверцетина в формировании качества мяса все еще требует изучения. В последние несколько лет появились сообщения, что кверцетин при длительном потреблении (до 6 мес, 0,2 \% в рационе) способен уменышать повреждение мышечных волокон в дистрофической скелетной мышце у лабораторных животных (72). Кроме этого, его скармливание предотвращает потери мышечной массы и развитие атрофии мышечной волокон за счет снижения образования перекиси водорода в митохондриях даже в случаях, когда атрофия вызвана травмированием нервной ткани мышц (73). 


\section{3. Мета-анализ данных по применению кверцетина (KB) и дигидрокверцетина (ДКВ) в качестве адаптогена в свиноводстве (ScienceDirect,}

1998-2019 годы)

\begin{tabular}{|c|c|c|c|c|c|}
\hline \multirow{2}{*}{$\begin{array}{l}\text { Предполагаемый } \\
\text { эффект }\end{array}$} & \multirow{2}{*}{\begin{tabular}{|} 
Число животных \\
в экспериментах
\end{tabular}} & \multicolumn{2}{|c|}{ Применение } & \multirow{2}{*}{ Вывод } & \multirow{2}{*}{ Источники } \\
\hline & & дозы & период & & \\
\hline Показатели роста & 10 & $\begin{array}{l}\text { ДКВ (Экостимул-2), } \\
1 \text { мг/кГ живой массы в } \\
\text { сутки); } \\
\text { КВ, } 25 \text { мг/кГ корма }\end{array}$ & $\begin{array}{l}\text { ДКВ - в период } \\
\text { воздействия теп- } \\
\text { лового стресса; } \\
\text { КВ - } 28 \text { сут }\end{array}$ & Повышается выживаемость и среднесуточные приросты массы животных & $(64,66,71)$ \\
\hline $\begin{array}{l}\text { Качественные характери- } \\
\text { стики туш }\end{array}$ & $\begin{array}{l}\text { Не сообщается } \\
\text { (изучалось мясо) }\end{array}$ & ДКВ & $\begin{array}{l}\text { С } 72 \text { кг до убоя } \\
(45 \text { сут) }\end{array}$ & ДКВ не повлияет на морфологический состав туш & $(67)$ \\
\hline $\begin{array}{l}\text { Содержание кверцетина в } \\
\text { крови, органах, мышечной } \\
\text { и жировой ткани живот- } \\
\text { ного }\end{array}$ & 10 & $\begin{array}{l}\text { КВ (агликон, кверцетин- } \\
\text { 3-О-глюкозид, рутин - } \\
\text { Кверцетин-3-О-глюкорам- } \\
\text { нозид), до } 65 \text { г/сут }\end{array}$ & До 10 сут & $\begin{array}{l}\text { Биодоступен. Биодоступность КВ зависит от его вида и рациона свиней, она } \\
\text { выше у глюкозида. Наибольшее содержание кверцетина и его метаболитов в } \\
\text { печени, тонком отделе кишечника, почках, плазме крови; низкое - в мозге, } \\
\text { сердце и селезенке. Нет тенденции к накоплению (нет разницы между одно- и } \\
\text { многократным применением) }\end{array}$ & $(51-55)$ \\
\hline $\begin{array}{l}\text { Состояние мышечной } \\
\text { ткани (результаты иссле- } \\
\text { дований на мышах) }\end{array}$ & $\begin{array}{l}\text { Не сообщается } \\
\text { (изучалось мясо) }\end{array}$ & КВ, 0,2 \% рациона & От 14 сут до 6 мес & $\begin{array}{l}\text { Длительное добавление КВ уменьшает повреждение в дистрофической } \\
\text { скелетной мышце, предотвращает потери мышечной массы и тормозит } \\
\text { развитие атрофии мышечной волокон за счет снижения образования перекиси } \\
\text { водорода в митохондриях }\end{array}$ & $(72,73)$ \\
\hline Состояние митохондрий & $\begin{array}{l}\text { Не сообщается } \\
\text { (изучалось мясо) }\end{array}$ & КВ, 0,2\% рациона & 14 сут & Снижает образование перекиси водорода митохондриях & (73) \\
\hline $\begin{array}{l}\text { Тяжесть последствий } \\
\text { транспортного стресса }\end{array}$ & 510 & $\begin{array}{l}\text { КВ, } 25 \text { мг/кг корма; } 1,25- \\
40 \text { мкг/мл (на клеточной } \\
\text { культуре) }\end{array}$ & $\begin{array}{l}28 \text { сут (с } 72 \text { до } \\
100 \text { кг) }\end{array}$ & $\begin{array}{l}\text { КВ лучше, чем витамин Е, смягчает негативный эффект транспортировки, вли- } \\
\text { яет на пролиферацию клеток эпителия, защищает от окислительного стресса, по- } \\
\text { ложительно влияет на целостность кишечника, уменьшает продукцию активных } \\
\text { форм кислорода в кишечнике и воспаление кишечника при транспортном стрессе }\end{array}$ & $(62,68,71)$ \\
\hline $\begin{array}{l}\text { pH, влагосвязывающая спо- } \\
\text { собность (ВСС) и доля мяса } \\
\text { PSE (pale soft exudative) }\end{array}$ & 376 & $\begin{array}{l}\text { КВ, 2,5-25,0 мг/кг корма } \\
\text { ДКВ, 3,5 и 7,5 мг/кГ жи- } \\
\text { вой массы в сутки }\end{array}$ & $\begin{array}{l}; 28-45 \text { сут; с } 60 \text { до } \\
110 \text { кг; за } 4 \text { ч до } \\
\text { отправки на убой }\end{array}$ & $\begin{array}{l}\text { Эффект КВ и ДКВ неоднозначен: } \mathrm{pH} \text { и ВСС они повышают или не изменяют, } \\
\text { потери при хранении - снижают или не изменяют. Предполагается, что КВ и ДКВ } \\
\text { замедляют скорость автолиза, но конечный рН не зависит от рациона свиней }\end{array}$ & $(67-70)$ \\
\hline $\begin{array}{l}\text { Накопление продуктов } \\
\text { окислительной порчи }\end{array}$ & 816 & $\begin{array}{l}\text { КВ, 25-900 мг/кг корма, } \\
10 \text { мг/кг живой массы в } \\
\text { сутки; } \\
\text { ДКВ, } 1,0-7,5 \text { мг/кг жи- } \\
\text { вой массы в сутки }\end{array}$ & $17-45$ сут; 24 ч & $\begin{array}{l}\text { КВ защищает ткани и органы от окислительного стресса, повышает накопле- } \\
\text { ние витамина Е. Влияние на антиокислительный статус поросят-отъемышей } \\
\text { противоречиво. Повышает и стабилизирует антиокислительный статус плазмы } \\
\text { крови, в сыворотке, мышцах и печени снижает тиобарбитуровое и перекисное } \\
\text { числа (меньше первичных и вторичных продуктов окисления липидов при хране- } \\
\text { нии как в мышцах, так и в жире). Более нагляден эффект при длительном хранении }\end{array}$ & $\begin{array}{l}(56,61-66 \\
68,70,71)\end{array}$ \\
\hline Цвет мяса & 340 & КВ, 25 мг/кг корма & $\begin{array}{l}\text { С } 74 \text { кг до конеч- } \\
\text { ной убойной массы }\end{array}$ & $\begin{array}{l}\text { КВ положительно влияет на цвет мяса через } 24 \text { ч после убоя, но эффект при- } \\
\text { знается незначительным }\end{array}$ & $(68,70)$ \\
\hline
\end{tabular}


Таким образом, несмотря на небольшое число источников по кверцетину и дигидрокверцетину, мета-анализ позволяет выделить перспективные направления исследований для выявления влияния кверцетина (дигидрокверцетина) на прижизненное формирование качества свинины. Среди них - изучение роли этих добавок в предотвращении пороков качества свинины, вызванных миопатией (табл. 3).

Подводя итог анализу публикаций по влиянию антиоксидантов разной природы при стрессах, поражающих микроструктуру мышечной ткани, следует отметить, что применение таких адаптогенов в промышленном животноводстве может стать важным элементом интенсивных технологий, обеспечивающих прижизненное формирование качества мяса. Экспертная оценка степени изученности предполагаемых эффектов каждого из трех адаптогенов представлена в таблице 4.

4. Экспертная оценка изученности потенциала применения адаптогенов в свиноводстве (ScienceDirect, 1995-2019 годы)

\begin{tabular}{|c|c|c|c|}
\hline Предполагаемый эффект адаптогена & Витамин E & Селен & $\begin{array}{c}\text { Кверцетин } \\
\text { (дигидрокверцетин) }\end{array}$ \\
\hline Влияние на показатели роста свиней & $4+$ & $1+$ & $3+$ \\
\hline Влияние на эффективность использования корма & $4+$ & $1+$ & $1+$ \\
\hline Влияние на убойные показатели & $4+$ & $4+$ & $1+$ \\
\hline Влияние на качественные характеристики свиных туш & $4+$ & $3+$ & $3+$ \\
\hline $\begin{array}{l}\text { Влияние на содержание адаптогена в крови, органах, } \\
\text { мышечной и жировой ткани животного }\end{array}$ & $4+$ & $4+$ & $3+$ \\
\hline Влияние на состояние клеточных мембран и митохондрий & $4+$ & $1+$ & $3+$ \\
\hline Влияние на состояние мышечной ткани & $3+$ & $2+$ & $2+$ \\
\hline Влияние на тяжесть последствий транспортного стресса & & & \\
\hline свиней & $4+$ & $4+$ & $4+$ \\
\hline $\begin{array}{l}\text { Влияние на накопление внутримышечного жира и общий } \\
\text { химический состав мышечной ткани }\end{array}$ & $3+$ & $1+$ & $1+$ \\
\hline Влияние на жирнокислотный состав внутримышечного & & & \\
\hline жира & $2+$ & $3+$ & $1+$ \\
\hline $\begin{array}{l}\text { Влияние на pH, влагосвязывающую способность (ВСС) и } \\
\text { долю мяса PSE (pale soft exudative) }\end{array}$ & $2+$ & $3+$ & $2+$ \\
\hline Влияние на накопление продуктов окислительной порчи & $4+$ & $2+$ & $2+$ \\
\hline Влияние на общую органолептическую оценку & $3+$ & $3+$ & * \\
\hline Влияние на цвет мяса & $2+$ & $2+$ & $3+$ \\
\hline Влияние на вкус и запах мяса & $3+$ & $3+$ & $1+$ \\
\hline Влияние на нежность мяса & $2+$ & $1+$ & $1+$ \\
\hline \multicolumn{4}{|c|}{$\begin{array}{l}\text { П р и м е ч а н и е. 4+ - масштабное изучение, однозначные выводы, вероятность новых знаний очень } \\
\text { низкая; } 3+- \text { изучено в значительном объеме, выводы согласованные, но есть вероятность получения но- } \\
\text { вых знаний; } 2+- \text { изучено недостаточно или нет однозначных выводов, высока вероятность получения } \\
\text { новых знаний; } 1+- \text { изучено крайне слабо или не изучалось совсем, требует дальнейшего изучения. }\end{array}$} \\
\hline
\end{tabular}

Итак, проведенный мета-анализ позволил сделать следующие выводы. Необходимо продолжить изучение двух ключевых аспектов возможного применения адаптогенов при производстве свинины - влияния антиоксидантов на повышение $\mathrm{pH}$ и влагосвязывающую способность мяса, а также на стабилизацию цвета и торможение окислительных процессов. Следует отметить, что в программы научных работ редко включают гистологические исследования. Вероятно, это связано с отсутствием высококвалифицированных специалистов-гистологов. Накопление данных о влиянии адаптогенов на функциональные и технологические характеристики свинины свидетельствует об их взаимосвязи с прижизненным состоянием мышечной ткани и о значимости исследований по минимизации рисков миопатии в условиях интенсивного производства свинины.

1ФГБНУ ФНЦ пищевых систем им. В.М. Горбатова РАН, 109316 Россия, г. Москва, ул. Талалихина, 26, e-mail: semmm@mail.ru, labsens@mail.ru,vvnas@mail.ru;

2ФГБНУ Федеральный научный иентр животноводства - ВИЖ им. академика Л.К. Эрнста,
Поступила в редакцию 10 августа 2020 года 


\title{
USE OF ANTIOXIDANTS AS ADAPTOGENS FED TO PIGS (Sus scrofa domesticus Erxleben, 1777) (META-ANALYSIS)
}

\author{
A.A. Semenova 1 , T.G. Kuznetsova1, V.V. Nasonova ${ }^{1}$, R.V. Nekrasov², N.V. Bogolyubova2, \\ E.Yu. Tsis ${ }^{2}$
}

${ }^{1}$ Gorbatov Federal Center for Food Systems RAS, 26, ul. Talalikhina, Moscow, 109316 Russia, e-mail semmm@mail.ru, labsens@mail.ru,vvnas@mail.ru;

${ }^{2}$ Ernst Federal Science Center for Animal Husbandry, 60, pos. Dubrovitsy, Podolsk District, Moscow Province, 142132 Russia, e-mail nek_roman@mail.ru ( $₫$ corresponding author),652202@mail.ru, tsis-elen@yandex.ru ORCID:

Semenova A.A. orcid.org/0000-0002-4372-6448

Kuznetsova T.G. orcid.org/0000-0002-5164-1807

Nasonova V.V. orcid.org/0000-0001-7625-3838

Nekrasov R.V. orcid.org/0000-0003-4242-2239

The authors declare no conflict of interests

Bogolyubova N.V. orcid.org/0000-0002-0520-7022

Acknowledgements:

Supported financially from Russian Science Foundation, project No. 19-16-00068

Received August 10, 2020

doi: 10.15389/agrobiology.2020.6.1107eng

\section{Abstract}

The meat flash quality is basically dependent on muscle tissue characteristics. Feeding disorders and stresses can cause myopathy, a destabilizing factor of farm animal meat quality. The muscle tissue injury preventing is of particular interest as it can improve lifetime meat quality formation. Dietary enrichment of farm animal nutrition with natural adaptogens and antioxidants offers potential to reduce myopathies of various etiologies. This paper is an overview of nutrition factors as protective agents under stress loads and myopathies in intensively growing pigs. Dietary adaptogens, e.g. selenium, tocopherol, quercetins, etc., inhibit peroxidation of lipids, generation of reactive oxygen species and are important for the control of glycolysis and oxidative stress. Most adaptogens are antioxidants, they have a beneficial effect on the cardiovascular system, including blood capillaries, prevent damage to cell membranes caused by free radicals and apoptosis. The beneficial effects of vitamin E-enriched diets (from 10 to $1000 \mathrm{mg} / \mathrm{kg}$ feed, approximately $200 \mathrm{mg} / \mathrm{kg}$ mainly) on porcine meat quality characteristics have been well studied in pig breeds and breed combinations during various periods of growing. However, no effect of dietary vitamin $\mathrm{E}$ on the growth rate of animals has also been reported. Feed enrichment with dietary tocopherol leads to its deposition in all tissues and organs, primarily in the blood, liver, heart, and in muscle and fat tissues. Vitamin E has a membrane-stabilizing effect, reduces oxidation of membrane lipids, increases the total amount of fatty acids in mitochondria, antioxidant capacity and muscle glycogen content. It has been shown that in pigs fed diets supplemented with vitamin $\mathrm{E}$ during fattening phase the vitamin $\mathrm{E}$ deposition level in meat is higher. This, in turn, improves meat taste and flavor, reduces the smell characteristic of reheated dishes, does not change the aldehyde profile of meat volatiles and reduces the accumulation of nitrogenous volatiles resulted from the breakdown of meat proteins during storage, including in a vacuum. Less attention is paid to administration of selenium as an adaptogen. It was shown that selenium combined with higher vitamin E level can neutralize the adverse consequences of hyperthermia in growing pigs and increase free fatty acid content in fat. The organic form of dietary selenium improves the antioxidant status of muscles in pigs. However, selenium has different effects on the oxidation of proteins and lipids during meat storage. In some studies, selenium reduced oxidation; in others, on the contrary, it was proved to be unable to inhibit the accumulation of products of oxidative damage. Two flavonoids quercetin and dihydroquercetin (Taxifolin) are well known for their antioxidant properties. The research articles are mainly deal with quercetin and dihydroquercetin bioavailability and deposition, the impact on antioxidant status and reproductive functions of sows, leveling transportation stress, and pork quality. Quercetin supplements have a pronounced effect at $25-50 \mathrm{mg} / \mathrm{kg}$ live weight, dihydroquercetin supplements at $1-3.5 \mathrm{mg} / \mathrm{kg}$ live weight. The flavonoids are effective when administered both during the fattening period and before slaughter or transportation. Despite the encouraging reports, little research has focused on the role of these flavonoids in the pork meat quality formation, so further study requires. Quercetin when fed up to 6 months at $2 \%$ of the diet reduced damage to dystrophic skeletal muscle fibers in laboratory animals due to a decrease in reduced production of hydrogen peroxide in mitochondria. Adaptogens and directed muscle tissue development regulators are proposed as potentially key supplements ensuring meat quality under intensive animal husbandry, therefore, further search for and study of bioactive substances which can protect muscle tissues from damaging factors are required.

Keywords: pigs, stress, pork, myopathy, adaptogen, antioxidant, selenium, vitamin E, quercetin, dihydroquercetin. 


\section{REFER E N C ES}

1. Listrat A., Lebret B., Louveau I., Astruc T., Bonnet M., Lefaucheur L., Bugeon J. Comment la structure et la composition du muscle déterminent la qualité des viands ou chairs? INRAE Productions Animales, 2015, 28(2): 125-136 (doi: 10.20870/PRODUCTIONS-ANIMALES.2015.28.2.3020).

2. Studentsov E.P., Ramsh S.M., Kazurova N.G., Neporozhneva O.V., Garabadzhiu A.V., Kochina T.A., Voronkov M.G., Kuznetsov V.A., Krivorotov D.V. Obzory po klinicheskoi farmakologii i lekarstvennoi terapii, 2013, 4(11): 3-43 (in Russ.).

3. Lebold K.M., Löhr C.V., Barton C.L., Miller G.W., Labut E.M., Tanguay R.L., Traber M.G. Chronic vitamin $\mathrm{E}$ deficiency promotes vitamin $\mathrm{C}$ deficiency in zebrafish leading to degenerative myopathy and impaired swimming behavior. Comparative Biochemistry and Physiology Part C: Toxicology \& Pharmacology, 2013, 157(4): 382-389 (doi: 10.1016/j.cbpc.2013.03.007)

4. Lauridsen C., Jensen C.L., Krogh S., Skibsted L.H., Bertelsen G. Influence of supranutritional vitamin $\mathrm{E}$ and copper on $\alpha$-tocopherol deposition and susceptibility to lipid oxidation of porcine membranal fractions of M. Psoas major and M. Longissimus dorsi. Meat Science, 2000, 54 (4): 377 384 (doi: 10.1016/S0309-1740(99)00113-8).

5. Bosi P., Cacciavillani J.A., Casini L., Lo Fiego D.P., Marchetti M., Mattuzzi S. Effects of dietary high-oleic acid sunflower oil, copper and vitamin E levels on the fatty acid composition and the quality of dry cured Parma ham. Meat Science, 2000, 54(2): 119-126 (doi: 10.1016/S03091740(99)00071-6).

6. O’Sullivan M.G., Byrne D.V., Stagsted J., Andersen H.J., Martens M. Sensory colour assessment of fresh meat from pigs supplemented with iron and vitamin E. Meat Science, 2002, 60 (3): 253265 (doi: 10.1016/s0309-1740(01)00131-0).

7. Isabel B., Lopez-Bote C.J., la Hoz L., Timyn M., García C., Ruiz J. Effects of feeding elevated concentrations of monounsaturated fatty acids and vitamin E to swine on characteristics of dry cured hams. Meat Science, 2003, 64(4): 475-482 (doi: 10.1016/S0309-1740(02)00225-5).

8. Daza A., Rey A.I., Ruiz J., Lopez-Bote C.J. Effects of feeding in free-range conditions stability or in confinement with different dietary MUFA/PUFA ratios and $\alpha$-tocopheryl acetate, on antioxidants accumulation and oxidative stability in Iberian pigs. Meat Science, 2005, 69 (1): 151-163 (doi: 10.1016/j.meatsci.2004.06.017).

9. Sárraga C., Guardia M.D., Díaz I., Guerrero L., García Regueiro J.A., Arnau J. Nutritional and sensory quality of porcine raw meat, cooked ham and dry-cured shoulder as affected by dietary enrichment with docosahexaenoic acid (DHA) and $\alpha$-tocopheryl acetate. Meat Science, 2007, 76(2): 377-384 (doi: 10.1016/j.meatsci.2006.12.007).

10. Boler D.D., Gabriel S.R., Yang H., Balsbaugh R., Mahan D.C., Brewer M.S., McKeith F.K., Killefer J. Effect of different dietary levels of natural-source vitamin $\mathrm{E}$ in grow-finish pigs on pork quality and shelf life. Meat Science, 2009, 83(4): 723-730 (doi: 10.1016/j.meatsci.2009.08.012).

11. Zou Y., Xiang Q., Wang J., Wei H., Peng J. Effects of oregano essential oil or quercetin supplementation on body weight loss, carcass characteristics, meat quality and antioxidant status in finishing pigs under transport stress. Livestock Science, 2016, 192: 33-38 (doi: 10.1016/J.LIVSCI.2016.08.005).

12. Zou Y., Hu M.X., Zhang T., Wei H.K., Zhou Y.F., Zhou Z.X., Peng J. Effects of dietary oregano essential oil and vitamin E supplementation on meat quality, stress response and intestinal morphology in pigs following transport stress. Journal of Veterinary Medical Science, 2017, 79(2): 328 335 (doi: 10.1292/jvms.16-0576).

13. Rosenvold K., Lærke H.N., Jensen S.K., Karlsson A.H., Lundström K., Andersen H.J. Manipulation of critical quality indicators and attributes in pork through vitamin E supplementation, muscle glycogen reducing finishing feeding and pre-slaughter stress. Meat Science, 2002, 62(4): 485-496 (doi: 10.1016/S0309-1740(02)00045-1).

14. Geesink G.H., Buren R.G.C., Savenije B., Verstegen M.W.A., Ducro B.J., van der Palen J.G.P., Hemke G. Short-term feeding strategies and pork quality. Meat Science, 2004, 67(1): 1-6 (doi: 10.1016/j.meatsci.2003.08.015).

15. Gebert S., Eichenberger B., Pfirter H.P., Wenk C. Influence of different dietary vitamin C levels on vitamin $\mathrm{E}$ and $\mathrm{C}$ content and oxidative stability in various tissues and stored $\mathrm{m}$. Longissimus dorsi of growing pigs. Meat Science, 2006, 73(2): 362-367 (doi: 10.1016/j.meatsci.2005.12.012).

16. Wang H., Wang L.S., Shi B.-M., Shan A.-S. Effects of dietary corn dried distillers grains with solubles and vitamin E on growth performance, meat quality, fatty acid profiles, and pork shelf life of finishing pigs. Livestock Science, 2012, 149(1-2): 155-166 (doi: 10.1016/J.LIVSCI.2012.07.009).

17. Huang C., Chiba L.I., Magee W.E., Wang Y., Griffing D.A., Torres I.M., Rodning S.P., Bratcher C.L., Bergen W.G., Spangler E.A. Effect of flaxseed oil, animal fat, and vitamin E supplementation on growth performance, serum metabolites, and carcass characteristics of finisher pigs, and physical characteristics of pork. Livestock Science, 2019, 220: 143-151 (doi: 10.1016/J.LIVSCI.2018.11.011). 
18. Dineen N.M., Kerry J.P., Lynch P.B., Buckley D.J., Morrissey P.A., Arendt E.K. Reduced nitrite levels and dietary $\alpha$-tocopheryl acetate supplementation: effects on the colour and oxidative stability of cooked hams. Meat Science, 2000, 55(4): 475-482 (doi: 10.1016/s0309-1740(00)00008-5).

19. Lauridsen C., Theil P.K., Jensen S.K. Composition of $\alpha$-tocopherol and fatty acids in porcine tissues after dietary supplementation with vitamin E and different fat sources. Animal Feed Science and Technology, 2013, 179 (1-4): 93-102 (doi: 10.1016/J.ANIFEEDSCI.2012.10.007).

20. Cava R., Ventanas J., Tejeda J.F., Ruiz J., Antequera T. Effect of free-range rearing and $\alpha-$ tocopherol and copper supplementation on fatty acid profiles and susceptibility to lipid oxidation of fresh meat from Iberian pigs. Food Chemistry, 2000, 68(1): 51-59 (doi: 10.1016/S03088146(99)00155-7).

21. Phillips A.L., Faustman C., Lynch M.P., Govoni K.E., Hoagland T.A., Zinn S.A. Effect of dietary $\alpha$-tocopherol supplementation on color and lipid stability in pork. Meat Science, 2001, 58(4): 389-393 (doi: 10.1016/S0309-1740(01)00039-0).

22. O’Sullivan M.G., Byrne D.V., Nielsen J.H., Andersen H.J., Martens M. Sensory and chemical assessment of pork supplemented with iron and vitamin E. Meat Science, 2003, 64(2): 175-189 (doi :10.1016/S0309-1740(02)00177-8).

23. Lahucky R., Bahelka I., Kuechenmeister U., Vasickova K., Nuernberg K., Ender K., Nuernberg G. Effects of dietary supplementation of vitamins D3 and E on quality characteristics of pigs and longissimus muscle antioxidative capacity. Meat Science, 2007, 77(2): 264-268 (doi: 10.1016/j.meatsci.2007.03.012).

24. Realini C.E., Pérez-Juan M., Gou P., Díaz I., Sárraga C., Gatellier P., García-Regueiro J.A. Characterization of Longissimus thoracis, Semitendinosus and Masseter muscles and relationships with technological quality in pigs. 2. Composition of muscles. Meat Science, 2013, 94(3): 417-423 (doi: 10.1016/j.meatsci.2013.03.007).

25. Kim J.C., Jose C.G., Trezona M., Moore K.L., Pluske J.R., Mullan B.P. Supra-nutritional vitamin E supplementation for 28 days before slaughter maximises muscle vitamin E concentration in finisher pigs. Meat Science, 2015, 110: 270-277 (doi: 10.1016/j.meatsci.2015.08.007).

26. Cheah K.S., Cheah A.M., Krausgrill D.I. Effect of dietary supplementation of vitamin E on pig meat quality. Meat Science, 1995, 39(2): 255-264 (doi: 10.1016/0309-1740(94)P1826-H).

27. Rossi R., Ratti S., Pastorelli G., Crotti A., Corino C. The effect of dietary vitamin E and verbascoside on meat quality and oxidative stability of Longissimus Dorsi muscle in medium-heavy pigs. Food Research International, 2014, 65(Part A): 88-94 (doi: 10.1016/J.FOODRES.2014.03.062).

28. Jin C.-L., Gao C.-Q., Wang Q., Zhang Z.-M., Xu Y.-L., Li H.-C., Yan H.-C., Wang X.-Q. Effects of pioglitazone hydrochloride and vitamin $\mathrm{E}$ on meat quality, antioxidant status and fatty acid profiles in finishing pigs. Meat Science, 2018, 145: 340-346 (doi: 10.1016/j.meatsci.2018.07.008).

29. Meineri G., Medana C., Giancotti V., Visentin S., Giorgio Peiretti P. Effect of dietary supplementation of vitamin $\mathrm{E}$ in pigs to prevent the formation of carcinogenic substances in meat products. Journal of Food Composition and Analysis, 2013, 30(2): 67-72 (doi: 10.1016/J.JFCA.2013.02.002).

30. Rajauria G., Draper J., McDonnell M., O’Doherty J.V. Effect of dietary seaweed extracts, galactooligosaccharide and vitamin E supplementation on meat quality parameters in finisher pigs. Innovative Food Science \& Emerging Technologies, 2016, 37(Part B): 269-275 (doi: 10.1016/j.ifset.2016.09.007).

31. Mahan D.C., Cline T.R., Richert B. Effects of dietary levels of selenium-enriched yeast and sodium selenite as selenium sources fed to growing-finishing pigs on performance, tissue selenium, serum glutathione peroxidase activity, carcass characteristics, and loin quality. Journal of Animal Science, 1999, 77(8): 2172-2179 (doi: 10.2527/1999.7782172x).

32. Silva V.A., Bertechini A.G., Clemente A.H.S., de Freitas L.F.V.B., Nogueira B.R.F., de Oliveira B.L., Ramos A.L.S. Different levels of selenomethionine on the meat quality and selenium deposition in tissue of finishing pigs. Journal of Animal Physiology and Animal Nutrition, 2019, 103(6): 1866-1874 (doi: 10.1111/jpn.13179).

33. Morel P.C.H., Leong J., Nuijten W.G.M., Purchas R.W., Wilkinson B.H.P. Effect of lipid type on growth performance, meat quality and the content of long chain n-3 fatty acids in pork meat. Meat Science, 2013, 95(2): 151-159 (doi: 10.1016/j.meatsci.2013.04.047).

34. Zhan X.A., Wang M., Zhao R.Q., Li W. F., Xu Z.R. Effects of different selenium source on selenium distribution, loin quality and antioxidant status in finishing pigs. Animal Feed Science and Technology, 2007, 132(3-4): 202-211 (doi: 10.1016/j.anifeedsci.2006.03.020).

35. Jiang J., Tang X., Xue Y., Lin G., Xiong Y.L. Dietary linseed oil supplemented with organic selenium improved the fatty acid nutritional profile, muscular selenium deposition, water retention, and tenderness of fresh pork. Meat Science, 2017, 131: 99-106 (doi: 10.1016/j.meatsci.2017.03.014).

36. Falk M., Bernhoft A., Framstad T., Salbu B., Wisløff H., Kortner T.M., Kristoffersen A.B., Oropeza-Moe M.O. Effects of dietary sodium selenite and organic selenium sources on immune and inflammatory responses and selenium deposition in growing pigs. Journal of Trace Elements in Medicine and Biology, 2018, 50: 527-536 (doi: 10.1016/j.jtemb.2018.03.003).

37. Son A.R., Jeong J.Y., Park K.R., Kim M., Lee S.D., Yoo J.H., Do Y.J., Reddy K.E., Lee H.J. 
Effects of graded concentrations of supplemental selenium on selenium concentrations in tissues and prediction equations for estimating dietary selenium intake in pigs. Peer J., 2018, 6: e5791 (doi: 10.7717/peerj.5791).

38. Calvo L., Segura J., Toldrá F., Flores M., Rodrhguez A.I., López-Bote C.J., Rey A.I. Meat quality, free fatty acid concentration, and oxidative stability of pork from animals fed diets containing different sources of selenium. Food Science and Technology International, 2017, 23(8): 716728 (doi: 10.1177/1082013217718964).

39. Calvo L., Toldrá F., Aristoy M.C., López-Bote C.J., Rey A.I. Effect of dietary organic selenium on muscle proteolytic activity and water-holding capacity in pork. Meat Science, 2016, 121: 1-11 (doi: 10.1016/j.meatsci.2016.05.006).

40. Vitali M., Sirri R., Zappaterra M., Zambonelli P., Giannini G., Lo Fiego D.P., Davoli R. Functional analysis finds differences on the muscle transcriptome of pigs fed an n-3 PUFA-enriched diet with or without antioxidant supplementations. PLoS ONE, 2019, 14(2): e0212449 (doi: 10.1371/journal.pone.0212449).

41. Liu F., Cottrell J.J., Leury B.J., Chauhan S., Celi P., Abrasaldo A., Dunshea F.R. Selenium or vitamin E mitigates hyperthermia in growing pigs. Journal of Nutrition \& Intermediary Metabolism, 2014, 1: 22 (doi: 10.1016/j.jnim.2014.10.073).

42. Calvo L., Toldrá F., Rodríguez A.I., López-Bote C., Rey A.I. Effect of dietary selenium source (organic vs. mineral) and muscle $\mathrm{pH}$ on meat quality characteristics of pigs. Food Science \& Nutrition, 2017, 5(1): 94-102 (doi: 10.1002/fsn3.368).

43. Mateo R.D., Spallholz J.E., Elder R., Yoon I., Kim S.W. Efficacy of dietary selenium sources on growth and carcass characteristics of growing-finishing pigs fed diets containing high endogenous selenium. Journal of Animal Science, 2007, 85(5): 1177-1183 (doi: 10.2527/jas.2006-067).

44. Li J.-G., Zhou J.-C., Zhao H., Lei X.-G., Xia X.-J., Gao G., Wang K.-N. Enhanced waterholding capacity of meat was associated with increased Sepw1 gene expression in pigs fed selenium-enriched yeast. Meat Science, 2011, 87(2): 95-100 (doi: 10.1016/j.meatsci.2010.05.019).

45. Chen J., Tian M., Guan W., Wen T., Yang F., Chen F., Zhang S., Song J., Ren C., Zhang Y., Song H. Increasing selenium supplementation to a moderately-reduced energy and protein diet improves antioxidant status and meat quality without affecting growth performance in finishing pigs. Journal of Trace Elements in Medicine and Biology, 2019, 56: 38-45 (doi: 10.1016/J.JTEMB.2019.07.004).

46. Nuernberg K., Kuechenmeister U., Kuhn G., Nuernberg G., Winnefeld K., Ender K., Cogan U., Mokady S. Influence of dietary vitamin E and selenium on muscle fatty acid composition in pigs. Food Research International, 2002, 35(6): 505-510 (doi: 10.1016/S0963-9969(01)00148-X).

47. Godziszewska J., Guzek D., Głąbska D., Jyźwik A., Brodowska M., Głąbski K., ZarodkiewiczM., Gantner M., Wierzbicka A. Nutrient oxidation in pork loin is influenced by feed supplementation and packing methods. Journal of Food Composition and Analysis, 2017, 56: 18-24 (doi: 10.1016/J.JFCA.2016.11.009).

48. Pogorzelska-Nowicka E., Godziszewska J., Horbańczuk J.O., Atanasov A.G., Wierzbicka A. The Effect of PUFA-rich plant oils and bioactive compounds supplementation in pig diet on color parameters and myoglobin status in long-frozen pork meat. Molecules, 2018, 23(5): 1005 (doi: 10.3390/molecules23051005).

49. Morel P.C., Janz J.A., Zou M., Purchas R.W., Hendriks W.H., Wilkinson B.H. The influence of diets supplemented with conjugated linoleic acid, selenium, and vitamin E, with or without animal protein, on the quality of pork from female pigs. Journal of Animal Science, 2008, 86(5): 11451155 (doi: 10.2527/jas.2007-0358).

50. Wojtasik-Kalinowska I., Guzek D., Gyrska-Horczyczak E., Głąbska D., Brodowska M., Sun D.-W., Wierzbicka A. Volatile compounds and fatty acids profile in Longissimus dorsi muscle from pigs fed with feed containing bioactive components. LWT - Food Science and Technology, 2016, 67: 112-117 (doi: 10.1016/J.LWT.2015.11.023).

51. Cermak R., Landgraf S., Wolffram S. The bioavailability of quercetin in pigs depends on the glycoside moiety and on dietary factors. The Journal of Nutrition, 2003, 133(9): 2802-2807 (doi: 10.1093/jn/133.9.2802).

52. Lesser S., Cermac R., Wolffram S. Bioavailability of quercetin in pigs is influenced by the dietary fat content. The Journal of Nutrition, 2004, 134(6): 1508-1511 (doi: 10.1093/jn/134.6.1508).

53. De Boer V.C.J., Dihal A.A., van der Woude H., Arts I.C.W., Wolffram S., Alink G.M., Rietjens I.M.C.M., Keijer J., Hollman P.C.H. Tissue distribution of quercetin in rats and pigs. The Journal of Nutrition, 2005, 135(7): 1718-1725 (doi: 10.1093/jn/135.7.1718).

54. Percival S.S. Commentary on: Tissue distribution of quercetin in rats and pigs. The Journal of Nutrition, 2005, 135(7): 1617-1618 (doi: 10.1093/jn/135.7.1617).

55. Bieger J., Cermak R., Blank R., de Boer V.C.J., Hollman P.C.H., Kamphues J., Wolffram S. Tissue distribution of quercetin in pigs after long-term dietary supplementation. The Journal of Nutrition, 2008, 138(8): 1417-1420 (doi: 10.1093/jn/138.8.1417).

56. Luehring M., Blank R., Wolffram S. Vitamin E-sparing and vitamin E-independent antioxidative 
effects of the flavonol quercetin in growing pigs. Animal Feed Science and Technology, 2011, 169(34): 199-207 (doi: 10.1016/J.ANIFEEDSCI.2011.06.006).

57. Santini S.E., Basini G., Bnssolaty S., Grasselli F. The phytoestrogen quercetin impairs steroidogenesis and angioqenesis in swine granulose cells in vitro. BioMed Research International, 2009, 2009: Article ID 419891 (doi: 10.1155/2009/419891).

58. Kang J.T., Moon J.H., Choi J.Y., Park S.J., Kim S.J., Saadeldin I.M., Lee B.C. Effect of antioxidant flavonoids (quercetin and taxifolin) on in vitro maturation of porcine oocytes. AsianAustralasia Journal of Animal Sciences, 2016, 29(3): 352-358 (doi: 10.5713/ajas. 15.0341).

59. Kang J., Kwon D., Park S., Kim S., Moon J., Koo O., Jang G., Lee B. Quercetin improves the in vitro development of porcine oocytes by decreasing reactive oxygen species levels. Journal of Veterinary Science, 2013, 14(1): 15-20 (doi:10.4142/jvs.2013.14.1.15).

60. Tarko A., Štochmal'ová A., Jedlicková K., Hrabovszká S., Vachanová A., Harrath A.H., Alwasel S., Alrezaki A., Kotwica J., Baláži A., Sirotkin A.V. Effects of benzene, quercetin, and their combination on porcine ovarian cell proliferation, apoptosis, and hormone release. Archives Animal Breeding, 2019, 62(1): 345-351 (doi: 10.5194/aab-62-345-2019).

61. Ma Z. The effect of dietary quercetin on the glutathione kinetics in the gut mucosa of weaned piglets. Master of Science in Nutrition and Rural Development. Gent University, 2016. Available: https://lib.ugent.be/en/catalog/rug01:002305194. Accessed: 15.09.2019.

62. Chen F., Yuan Q., Xu G., Chen H., Lei H., Su I. Effects of quercetin on proliferation and $\mathrm{H}_{2} \mathrm{O}_{2}-$ induced apoptosis of intestinal porcine enterocyte cells. Molecules, 2018, 23(8): 2012 (doi: 10.3390/molecules23082012).

63. Thanh B.V.L., Lemay M., Bastien A., Lapointe J., Lessard M., Chorfi G., Guay F. The potential effects of antioxidant feed additives in mitigating the adverse effect of corn naturally contaminated with Fusarium mycotoxin on antioxidant systems in intestinal mucosa, plasma, and liver in weaned pigs. Mycotoxin Research, 2016, 32(2): 99-116 (doi: 10.1007/s12550-016-0245-y).

64. Nikanova L.A., Fomichev Yu.P. Rossiiskii zhurnal «Problemy veterinarnoi sanitarii, gigieny $i$ ekologii», 2012, 1(7): 62-65 (in Russ.).

65. Fomichev Yu.P., Nikanova L.A., Kleimenov R.V., Netecha Z.A. Veterinarnaya meditsina, 2010, 5-6: 30-32 (in Russ.).

66. Nikanova L.A., Fomichev Yu.P. V sbornike: Nauchn. trudy Severo-Kavkazskogo nauchno-issledovatel'skogo instituta zhivotnovodstva, 2016, 5(2): 89-96 (in Russ.).

67. Ivanova S.G., Nakev J.L., Nikolova T.I., Vlahova-Vangelova D.B., Balev D.K, Dragoev S.G., Gerrard D.E., Grozlekova L.S., Tashkova D.A. Effect of new livestock feeds' phytonutrients on productivity, carcass composition and meat quality in pigs. Available: https://agrixiv.org/jfrvy/download/?format=pdf. $\quad$ Accessed: $\quad 13.08 .2019 \quad$ (doi: 10.31220/osf.io/jfrvy).

68. Zou Y., Wei H.K., Xiang Q.-H., Wang J., Zhou Y.-F., Peng J. Protective effect of quercetin on pig intestinal integrity after transport stress is associated with regulation oxidative status and inflammation. Journal of Veterinary Medical Science, 2016, 78(9): 1487-1494 (doi: 10.1292/jvms.160090).

69. Kremer B.T., Stahly S., Sebranek J.G. Effect of dietary quercetin on pork quality (1999). Iowa State University. Swine Research Report, 1998, 65. Available: http://lib.dr.iastate.edu/swinereports_1998/65. Accessed: 10.09.2019.

70. Vlahova-Vangelova D.B., Dragoev S.G., Balev D.K., Ivanova S.G., Nikolova T.I., Nakev I.L., Gerrard D.E. Improving the oxidative stability of pork by antioxidant type phytonutrients. University of Food Technologies, Technological Faculty, Department of Meat and Fish Technology, Bulgaria. Available: https://agrirxiv.org/search-details/?pan=20203203578. Accessed: 02.07.2020 (doi: 10.31220/osf.io/gz39p).

71. Zou Y., Xiang Q., Wang J., Wei H., Peng J. Effects of oregano essential oil or quercetin supplementation on body weight loss, carcass characteristics, meat quality and antioxidant status in finishing pigs under transport stress. Livestock Science, 2016, 192: 33-38 (doi: 10.1016/J.LIVSCI.2016.08.005).

72. Hollinger K., Shanely R.A., Quindry J.C., Selsby J.T. Long-term quercetin dietary enrichment decreases muscle injury in mdx mice. Clinical Nutrition, 2015, 34(3): 515-522 (doi: 10.1016/j.clnu.2014.06.008).

73. Mukai R., Matsui N., Fujikura Y., Matsumoto N., Hou D.-X., Kanzaki N., Shibata H., Horikawa M., Iwasa K., Hirasaka K., Nikawa T., Terao J. Preventive effect of dietary quercetin on disuse muscle atrophy by targeting mitochondria in denervated mice. The Journal of Nutritional Biochemistry, 2016, 31: 67-76 (doi: 10.1016/j.jnutbio.2016.02.001). 